\title{
Fanconi Anemia Group G Protein
}

National Cancer Institute

\section{Source}

National Cancer Institute. Fanconi Anemia Group G Protein. NCI Thesaurus. Code C26135.

Fanconi anemia group G protein ( $622 \mathrm{aa}, \sim 69 \mathrm{kDa}$ ) is encoded by the human FANCG gene. This protein may be involved in DNA damage repair and cell cycle checkpoint regulation. 